\title{
Atomic Routes and Cultures for a New Narrative on Franco's Regime
}

\author{
Ana Romero de Pablos \\ Instituto de Filosofía, CSIC \\ e-mail: ana.romero@cchs.csic.es \\ ORCID iD: https://orcid.org/0000-0002-5911-5887
}

Submitted: 1 April 2020. Accepted: 3 September 2020.

\begin{abstract}
A decision by two Spanish companies to start producing nuclear-based electrical energy was the beginning of a journey that led two Spanish engineers to the United States and Canada in 1957. They wanted to learn about the reactor technology that North American companies were developing, contact specialized consultants to explore possible consultancy services, and search out political, economic, and financial support to make their project viable. The trip's travel log suggests that the route they set off on was decisive in convincing the dictatorship's political, industrial, and economic powers of the importance of nuclear energy; this journey had a direct influence on subsequent construction of Spanish nuclear facilities and on the policies designed to manage it. In this article I suggest exploring this journey and its record to reflect on how nuclear energy participated in building a new narrative on the Franco regime, one that showed Spain as a modern, internationally-connected State capable of incorporating the latest atomic technologies.
\end{abstract}

KEYWORDS: Nuclear energy; Reactor technology; Nuclear power plants; Atomic power; Electrical industry; Francoist regime; Spain.

Citation / Cómo citar este artículo: Romero de Pablos, Ana (2021) "Atomic routes and cultures for a new narrative on Franco's Regime”. Culture \& History Digital Journal, 10 (1): e005. https://doi.org/10.3989/chdj.2021.005

RESUMEN: Rutas y culturas atómicas para una nueva narrativa del franquismo. La decisión de dos empresas españolas de lanzarse a producir energía eléctrica de origen nuclear puso en marcha un viaje que llevó en 1957 a dos ingenieros españoles a Estados Unidos y Canadá. Querían conocer la tecnología de los reactores que las firmas norteamericanas estaban desarrollando, contactar con consultoras especializadas para sondear posibles asesorías y buscar apoyos políticos, económicos y financieros que hicieran viable su proyecto. El cuaderno que registró el viaje sugiere que la ruta que emprendieron resultó determinante para convencer a los poderes políticos, industriales y económicos de la dictadura; tuvo un influjo directo en la posterior construcción del parque atómico español y en el diseño de las políticas que lo gestionaron. En este artículo propongo ese viaje y su registro para reflexionar sobre cómo la energía nuclear participó de la construcción de una nueva narrativa del franquismo que mostró a España como un Estado moderno, conectado internacionalmente y capaz de incorporar las últimas tecnologías atómicas.

PALABRAS CLAVE: energía nuclear; tecnología de reactores; centrales nucleares; poder atómico; industria eléctrica; franquismo; España.

Copyright: $\odot 2021$ CSIC. This is an open-access article distributed under the terms of the Creative Commons Attribution 4.0 International (CC BY 4.0) License. 
On September 22, 1971, Franco inaugurated the Santa María de Garoña nuclear power plant near Miranda de Ebro (Burgos). He was accompanied by the Ministers of Industry and Public Works, José María López de Letona and Gonzalo Fernández de la Mora, the Commissioner for Development Plans, Laureano López Rodó, and the Archbishop of the Diocese of Burgos. This was the culmination of a project that had begun in 1957 when two Spanish electricity companies-Iberduero and Electra del Viesgo-decided to unite their plans, creating Nuclenor (Nucleares del Norte). The plan was to begin construction on a nuclear power plant that could supply an increase in demand for electricity that reports from experts in both companies and also from the Ministry of Industry estimated would be created in northern Spain in the 1960s and 1970s.

Fourteen years passed from the start of the project to when the power plant was connected to the Spanish electricity network. During this time there were many books, reports, plans, people and major artifacts that traveled and circulated from one side of the Atlantic to the other. I have used as a source for this article the travel log that recorded the trips and impressions from the journey made by the two engineers, Manuel Gutiérrez-Cortines and Francisco Albisu, to the United States and Canada in 1957. ${ }^{1}$ This $\log$ is a material scientific object that had its own agency in the construction of Spanish atomic knowledge, and I propose it should also be read as a political and diplomatic object that had an influence on policy changes from the Franco regime, beginning with the Stabilization Plan of 1959.

Throughout history, generally, and in the history of science and technology, in particular, journeys have played a leading role in the construction of knowledge. The close connection between traveling, experimenting, and gaining knowledge, which is so nicely suggested in works on scientific expeditions (Pimentel, 2003; Bleichmar, 2012) or those reflecting on journeys for training and extended studies (Santesmases, 2007; López-Ocón, Guijarro, Pedrazuela, 2018; Velasco Morgado, 2019), have been a great inspiration in this work. And others have as well, such as works arguing that not all knowledge travels well in texts and that experimental practice is also necessary (Daston, 2000; Bud, 2007) and those that have shown the role that scientific artifacts have also played in political and diplomatic negotiations (Romero de Pablos, 2019a). All of them open up an interesting historiographic space to reflect not only on the direct influence this journey and its materialities had on the construction of Spanish nuclear facilities but also on the standing they provided to construct a new geopolitical narrative on the Franco regime, another of this article's proposals.

This journey, like so many others, showed Spain's intention to change and its desire for integration into the Western bloc. ${ }^{2}$ Although support for North American atomic policies and the expansion of its industry into Spanish territory was not viewed favorably by all - there were endless debates between supporters of encouraging development of the national industry versus purchasing foreign technology - they did introduce changes that were soon perceived in speeches and autarkic policies of the Franco regime: It took little time for Spain and its electrical industry to become the leading atomic partners for the Americans in Europe (Rubio Varas and De la Torre, 2017).

But I want to go further in this article, to show the close connection between traveling, experimenting and gaining knowledge. In order to establish a more effective dialogue with other historians, I lay out the knowledge, experiences and desires this trip put into circulation, that 'knowledge in transit' paraphrasing James A. Secord (2004), to suggest that Spain's commitment to nuclear energy had a direct influence on the construction of a new narrative from the Franco regime, one that sought to show this country as a modern, internationally-connected State capable of incorporating the latest atomic technologies.

I

Iberduero and Electra del Viesgo were the first Spanish electricity companies to make their desire to take a chance on nuclear energy public. The first company had a dominant position in the electricity market in northern Spain and Electra del Viesgo was the company responsible for supplying electricity to Santander (Garrués, 2006, pp. 497-573).

Studies carried out in the mid-1950s by the Ministry of Industry, Iberduero and Electra del Viesgo forecast that an increase in energy demand in northern Spain was going to take place in the 1960s and 1970s. It was in this context that the two electricity companies began to assess the construction of a nuclear power plant. But the technical and financial effort involved in the project made it unadvisable to be handled individually. This was when they chose to join forces and integrate their projects, which was the origin of Centrales Nucleares del Norte (Nuclenor, the Northern Nuclear Power Plants).

Although Nuclenor was the first to apply for permission from the Ministry of Industry, which they did in 1958, to build Santa María de Garoña, this was the second nuclear power plant to be put into operation in Spain. The project presented in 1962 by Unión Eléctrica Madrileña got a head start on them-the Zorita nuclear power plant in Guadalajara began to operate in 1968-with a technically less-ambitious proposal that was designed to supply the center of the peninsula. The Ministry of Industry chose to show the virtue of prudence, arguing that the Zorita project was more feasible and less costly, and to treat the political will I suggest was behind this decision as secondary: to prioritize and strengthen the energy supply in the center of the peninsula as opposed to the north. This, even though various studies on energy needs had already stated, as we will see below, that there would be an increase in demand in the northern part of the peninsula. In this sense, prioritizing Zorita over Garoña can be interpreted as another way of strengthening and making visible the unique and centralized power of the Francoist State. 
In order to really understand Nuclenor's commitment, it needs to be put in dialogue with a certain euphoria and what John Krige (2010) called 'the education of desire' for nuclear culture, which had produced the first International Conference on the Peaceful Uses of Atomic Energy held in Geneva in August 1955. A large group of Spanish politicians and industrialists participated in this, and Manuel Gutiérrez-Cortines, then managing director of Electra del Viesgo, was one of them (Romero de Pablos, 2018a). The large body of work done on this conference from the history of science, political history, the history of diplomacy and history of communication show the impact and significance it had on later development of this new form of energy (Medhurst, 1997; Krige, 2006; Osgood, 2006; Zachmann, 2011; Mateos and Suárez-Díaz, 2015; Drogan, 2016).

The new forms of international cooperation that the first Geneva Conference helped to launch turned science and technology, in general, and atomic energy, in particular, into political and diplomatic agents. And Nuclenor's leaders understood this when, in 1957, they decided to consider producing energy from nuclear sources. They knew from the beginning they had to convince, and not only within Spain, the various actors - political, financial and social - about the opportuneness of the project they were looking to begin. Manuel Gutiérrez-Cortines, then the newly appointed Vice President and CEO of this new entity, was aware of the doubts existing about reactor technology, how it worked and, above all, its profitability. That is why, when they began to think about how to deal with this ambitious project, it was clear to Gutiérrez-Cortines that they had to travel to learn about the various testing and projects that other countries had already begun. It was, in his view, the only way to make the right choice in regard to the type of reactor that best suited Nuclenor's energy and economic needs.

This was the origin of a trip that although initially aimed at learning about the different testing and projects that American and Canadian companies were undertaking, also served to provide arguments and reinforce Spanish technocrats who thought that economic growth should be based on the country's industrialization and modernization (Delgado, 2015).

When on October 30, 1957, a few months after establishing the partnership, Manuel Gutiérrez-Cortines and Francisco Albisu began their journey, it was not long until the National Trade Union Economic Council would talk about, at its annual meeting in December 1957, the urgent need to exploit nuclear energy industrially in Spain. They were a little more than a year ahead of the Minister of Industry, Joaquín Planell, who took up this issue again in the Spanish Parliament in his speech presenting the Law on Investigation and Exploitation of Radioactive Materials. ${ }^{3}$ And two more years passed before Franco and his government, through the Stabilization Plan of 1959, protected and promoted trade and financial exchanges with the outside world by introducing more permissive legislation that was open to foreign investment (Carreras and Tafunell, 2007).
As such, I propose that this trip played a part in constructing this new national and international narrative, which as of the 1960s showed the Francoist State as an internationally connected State capable of incorporating the latest atomic technologies. (On the participation of certain groups of engineers in some of the political and economic transformations that took place during the Franco regime, see Camprubí, 2017; for the specific case of nuclear development, Chapter 9).

The trip brought together two engineers coming from different generations and with different career paths. Manuel Gutiérrez-Cortines, trained at the Faculty of Industrial Engineers in Madrid, brought experience in electricity companies with him when he joined Electra del Viesgo in 1941 as managing director: he had worked at Standard Eléctrica since 1925, where he became general director and president of its Portuguese subsidiary in 1935. Francisco Albisu was also an industrial engineer but had been trained at the Faculty of Engineering in Bilbao. His early work was developed at the Laboratory of Industrial Research and Testing (LABEIN), which had been promoted in 1955 by Leandro José de Torróntegui, one of the Spanish industrialists who had also attended the first Geneva Conference (Urdangarín, 2018). In 1956, Albisu enrolled in the first Introduction to Nuclear Engineering course taught in Spain. Organized by the Theoretical Physics and Reactor Calculation Division of the Nuclear Energy Board (JEN in its Spanish acronym), it was the first to offer students hands-on practice with a Van der Graaff accelerator and a Cockroft-Walton neutron accelerator (Barca, 2000, p. 39; Romero de Pablos and Sánchez Ron, 2001, pp. 126 and 127) ${ }^{4}$. Following this course, in September 1956 he traveled to the Massachusetts Institute of Technology (MIT) where he did a Master of Science in Nuclear Engineering (Rubio-Varas and de la Torre, 2018, pp. 101 and 102). So, when Gutiérrez-Cortines commented to Leandro José de Torróntegui on his willingness to travel to the United States and the trip's objectives, the latter suggested that Francisco Albisu, young, well-trained and knowledgeable about the North American industry, would be an excellent traveling companion. ${ }^{5}$

As the Spanish engineers were fully aware of the hybrid and easily-permeated space they would be dealing with, they decided that in order to contrast the varied, certainly self-interested, information they were going to receive, they would combine visits to different research centers, construction companies, and nuclear installations with meetings with North American atomic policy decision-makers, leading engineering consultants and managers of North American industrial banks; they also wanted to evaluate possible economic and financial support for the project.

The account of the trip that began October 30 and ended on November 22 shows that the Spanish engineers were aware of the problems they had to face and not at all complacent about the facilities they visited or the interlocutors who received them. The many technical and organizational issues the North American industry still had pending to resolve were also noted in the travel $\log$. 
II

Although reactor models such as the Soviet RBMK and Canadian CANDU were already in operation at the end of the 1950s (Marcus, 2010, pp. 110 and 111, 184 and 185) and other types of reactors were under study, only two technologies had achieved an optimal degree of development globally for large-scale production of nuclear-derived electrical energy. The first, developed in the United States, was based on two reactor types, the pressurized water reactor (PWR) and boiling water reactor (BWR) (Marcus, 2010, pp. 99-101 and 104-106). What both have in common is that they use slightly enriched uranium as fuel and are cooled and moderated by water. But they differ in that in the second case the reactor coolant circuit is separated from the water-steam circuit by steam generators. This arrangement, although more expensive, prevents the heaters and condenser from being within the area exposed to radiation. And the second technology that was already on the market in the late 1950s were the natural uranium reactors, with graphite and gas, developed in Great Britain and France, known as MAGNOX and UNGG, respectively. These reactors used natural uranium as fuel, graphite as the moderator, and carbon dioxide gas as the heat exchange coolant (Marcus, 2010, pp. 130-132).

In the first two power plants installed in Spain, the North American technology was chosen: Zorita with the PWR type and Garoña with the BWR. In the third, Vandellòs opted for French technology (UNGG). In the rest of the Spanish nuclear facilities, North American technology dominated with PWR reactors being the majority, the exception being Trillo, which would incorporate German technology in the 1980s. (To learn about the technology used in each of the Spanish nuclear power plants see Rubio Varas and De la Torre, 2017, pp. 250-254).

The interest of Nuclenor's engineers in learning about the different types of reactors the nuclear industry and North American national laboratories were working on led them to visit the Argonne National Laboratory in Chicago first. This laboratory, which had been formally opened in 1946, originated from the "Manhattan Project," a project led by the United States and backed by the United Kingdom and Canada which had built the first nuclear bombs during World War II. (For the history of this laboratory see Holl, Hewlett and Harris, 1997; for the Manhattan Project see Reed, 2014). There, the Spanish engineers had their first contact with research reactors-the AEROJET and ARGONAUT models (Nuclear Assembly for University Training) - and with a type of boiling water power reactor.

They were interested in knowing the scope of the research reactors because they were considering the possibility of installing these types of reactors to train students both in the Faculty of Industrial Engineering in Bilbao and in Barcelona. Cortines and Albisu saw both of the models in operation and had access to the complete collection of drawings and plans for each one. Even so, before travelling they had learned about the Report AML-5704.
ARGONAUT, Argonne's Nuclear Assembly for University Training, which included a simplified edition of these plans. Seeing both reactors working gave them skills and knowledge that would be difficult to extract from any report, no matter how complete. ${ }^{6}$ This information, together with on-site experience in the laboratory, convinced them that the ARGONAUT reactor offered more possibilities and would be more useful to them in training future engineers. Furthermore, having a set of drawings with calculations and how to assemble the parts would facilitate possible construction and replication of this type of reactor in Spain.

But the record of the visit shows that the engineers from Nuclenor knew that, in order to replicate a reactor of this type in Spain, they had to take an interest in other details that went beyond the reactor's performance and its suitability for research and teaching:

We visited the ARGONAUT. The building is of a normal type of about $12 \times 20$ meters of floor space and with a height of about seven meters. The reactor is at one end, it does not need an exclusion zone (...). A simple jib crane was installed because it is cheaper, but they think that, if possible, an overhead crane can be installed. The concrete blocks for shielding are loose to make it easier to move them around. There are no warning signals in the building. Mr. Bryant [Harry Bryant, one of the physicists who accompanied them on the visit] says training is very good with this reactor. You can start by building the subcritical reactor and then continue until the entire reactor is complete. He insists that maturity in this field is achieved by learning while doing things. The control panel is similar to the one in a large power plant. The reactor is inherently safe; there are no wastewater problems (...). THE ARGONAUT is much more flexible than the AEROJET. Many things can be modified. Many accessories, thermal columns, etc., can be added to it. ${ }^{7}$

The Argos and Arbi reactors that were finally built in the JEN and installed in the Faculty of Engineering both in Bilbao and Barcelona, respectively, in 1961 demonstrated and convinced those responsible for the Spanish nuclear industry and policies that the transfer of knowledge and practices between the North American and Spanish laboratories was possible (for a technical report on the construction of these reactors see Fernández Palomero, Álvarez del Buergo and Sostoa Esquiroz, 1959: 18-37; Albisu and Echevarría, 1963).

The first power reactor that Cortines and Albisu saw was also at the Argonne National Laboratory, where they had installed a 5 MW BWR reactor. They knew this technology had been the focus of attention a year earlier at the Atomic Industrial Forum meetings $;^{8}$ and they also knew of the growing interest it was raising to the detriment of PWR reactors, until then the figurehead of the North American power reactor industry. This visit, along with a previous conversation they had upon their arrival in New York with an engineer at General Electric who had spoken to them about the advantages of BWR reactors, put 
them in a situation that would be constantly repeated for the rest of the trip, and which shows the fragile border between knowledge, technological information, and economic and industrial interests: General Electric had opted for development of BWR reactors, so the comments and assessments made by this engineer were always going to be mediated by that decision.

For the Spanish engineers, as important as knowing the reactors' technical details and seeing them operate was seeing that the supposed technological advantages that some types of reactors had for certain people were not so advantageous for others. So Cortines and Albisu also tried to find out what opinion the North American electricity companies were having about the new nuclear technology.

Commonwealth Edison, one of Chicago's leading electricity producers, was the first electricity company they visited. This company had been one of the first to trust the BWR reactors built by General Electric. According to what the Spaniards wrote in their travel log, for the Chicago electricity company this technology was the most reliable and General Electric the best company to build it: "If there is any type of reactor that presents a favorable outlook so far it is the boiling water and GE (sic) is the best organization to build it"9. An assessment that, contextualized in the time it was expressed, acquires a meaning that goes beyond an exclusively technical evaluation. When the technicians at Commonwealth Edison shared this comment with the Spanish visitors, the company was still three years away from putting into operation at the Dresden nuclear power plant (Illinois, Chicago)which it did in June 1960-the first of the three BWR reactors they had purchased from General Electric. This nuclear power plant was the first privately-funded plant in the United States to produce electricity on a large scale (Marcus, 2010, pp. 180 and 181).

The next stops Cortines and Albisu made, at the California facilities General Electric had in Vallecitos and San Jose, confirmed for them the idea that a BWR reactor from this firm could be one of the options to evaluate for the plant project. The reproduction in Vallecitos, on a $1 / 10$ scale, of the fuel elements used in Dresden and construction in the San Jose factory of a large water tank with identical dimensions to those of the reactor core were not only helpful for General Electric in doing hydraulic and thermal tests under real conditions, but were also useful in convincing potential buyers of the viability and reliability of their technology. In fact, the experience gained with the construction of this power plant was widely-used by General Electric later to give credibility to subsequent projects they used to compete in various tenders.

But the BWR reactors were not the only ones to grab the attention of the Spanish engineers. At the facility of Atomics International - a division of the North American Aviation company created to develop nuclear technology - in Canoga Park, California, they learned the details of an experimental program, the Sodium Reactor Experiment (SRE), with which this North American manufacturer wanted to check the technical and economic viability of reactors that were cooled by sodium and moderated by graphite. Although this experimental facility had been in operation for just three years, the results they had achieved so far had proved convincing: In November 1957, the time of the visit by the Spanish engineers, a reactor of this type was supplying electricity since July 12 of this same year to the California city of Santa Susana (Marcus, 2010, pp. 146-149). While this was the first contact that engineers from the Spanish industry established with Atomics International, we will see later that it was not the only one. The connection that was established with this facility from this moment on is another example of how this trip opened up routes and created relationships that not only later influenced projects, but also marked policies that were useful for the Francoist State to get attention by forming part of the international atomic network.

In addition to the General Electric and Atomics International facilities, Cortines and Albisu also went to those that Westinghouse had in Pittsburgh (Pennsylvania). This was a company that was already prominent at the time for building PWR reactors; it had a $60 \mathrm{MWe}$ one that was about to start up at the Shippingport nuclear power plant, which was inaugurated on December 18, 1957, in Beaver County (Pennsylvania) (Marcus, 2010: 156), and two others under project: one for Pennsylvania Power \& Light Company and another for the Yankee Rowe nuclear power plant that the Yankee Atomic Electric Company planned to build in Massachusetts.

Nuclenor's engineers knew from before they began their journey - the travel plan confirms this - that to catch up on reactor technology they had to contact, as we have seen, national laboratories, manufacturers, and North America's private industry. But the various meetings they were having were showing them other possible interlocutors who were not in the initial plan, ones with influence and power in the building of this technology. Thus, contacting consulting companies specialized in reactor engineering and banks able to finance their project was of interest to them and took up as much, or more, time as the technology.

Therefore, one of the meetings that would most define the trip was the one they had with the nuclear physicist Walter Zinn. Obtaining his support would not only technically legitimize the Garoña project; his expert opinion would provide tools and procedures for the Nuclenor engineers as well as the politicians in charge. The work he had developed in the Metallurgical Laboratory (Met Lab) of the Manhattan Project and later with the construction of Chicago Pile- $1,{ }^{10}$ the first research nuclear reactor that had begun operating in 1942 at the University of Chicago (Marcus, 2010, pp. 20-22), distinguished him as an indispensable advisor in the field of reactor physics as well as in the area of fuels. The experience of Walter Zinn, who had led the Argonne National Laboratory from 1946 to 1956, where he had designed and built the Experimental Breeder Reactor (EBR) - the first nuclear reactor to produce electricity, in December 1951 (Marcus, 2010, pp. 84 and 85) - combined two spaces, those of research and industry, which the Spaniards were interested in seeing 
connected. In addition, this physicist had left the Argonne National Laboratory in 1956 to establish his own consulting company, General Nuclear Engineering, in Florida. This other circumstance made it even more attractive to have him as an interlocutor.

In Spain in the 1950s, the brunt of research on atomic matters was located and centralized in the JEN; that was why seeing the possibility of converting industrial spaces into research sites as well was so appealing to the Spanish engineers. This change, which would take place in Spain as of the mid-1960s with the launch of nuclear power plant projects, not only introduced new forms of relationships between the JEN and the electrical industry, but also modified policies-the Nuclear Energy Law of 1964 is a good example of this - and shifted the research agenda from the JEN to the electric companies (Romero de Pablos, 2019b).

The meeting with Zinn took place on November 12, 1957, in Washington. Cortines and Albisu shared with him the Spanish power plant project, verified their confidence in the BWR reactors-his consulting firm had participated in the design and construction of severaland secured his commitment as a possible consultant if the Spanish project moved forward. A commitment that in the end only materialized with the plant's preliminary studies - specifically, he concerned himself with the work related to the search for a possible site-but which he did not want to extend to the construction stage. During this period, consultants would be hired such as INTERNUCLEAR, specialists like Walter Zinn's consultancy in reactor physics, and others such as EBASCO, Gibbs \& Hill and Bechtel, who shared extensive experience in nuclear power plant engineering.

The desirability of attracting and involving the North American political, economic, and financial powers in the Spanish project was also present in the various conversations the Nuclenor engineers held with the technology manufacturers, as well as with executives from the consulting companies. Therefore, visiting the United States Atomic Energy Commission (US AEC) was another priority on the trip. They did so almost near the end, accompanied by an executive from General Electric and José María de Areilza, Spain's ambassador to Washington from 1954 to 1960.

Areilza had a good dialogue going with the US AEC. $\mathrm{He}$ had experienced first-hand the circumstances in which President Eisenhower had launched the political program for research and nuclear development, 'Atoms for Peace,' and the development of what had been this program's first success, the first Geneva Conference in 1955. In addition, on July 19, 1955, as a representative of the Spanish government, he had signed with Admiral Strauss, the President of the US AEC, the bilateral cooperation agreement on atomic energy. ${ }^{11}$ At the time of the visit of Gutiérrez-Cortines and Albisu on November 13, 1957, Areilza was just finalizing negotiations for the purchase of Jen 1, the first research reactor to be installed in Spain (Romero de Pablos and Sánchez Ron, 2001, pp. 127-135).
At the US AEC, Cortines and Albisu held a first meeting with John A. Hall and Allen J. Vander Weyden, respectively director and deputy director of the International Affairs Department of this organization. The cooperation of Vander Weyden in drafting the report from the "Three Wise Men" of Euratom not only provided guarantees and endorsed the opinions they might have about the Spanish project, which they found to be precise and realistic in regard to deadlines, but would also pave the way to obtain permits from the Ministry of Industry. ${ }^{12}$ The second meeting was held with V. Packer and John P. Trevithick, European directors of the Reactor Development Department of the US AEC. This second meeting was useful for the Spanish engineers to expand the information they had obtained on Argonaut-type research reactors at the beginning of their trip on their visit to the Argonne National Laboratory. In addition to increasing the list of possible suitable manufacturers for this reactor type, at this meeting they also learned that, just like the engineering faculties in Bilbao and Barcelona, Stanford University had among its plans to build this type of reactor. A fact they liked knowing because they thought it could help with possible support from the Spanish government for the initiative from the Spanish faculties. These meetings at the US AEC were important; having the support of the US government agency that controlled and led the development of atomic energy globally helped pave the way and accelerate Nuclenor's plans in Spain.

The discussions they held with representatives from the State Department, Chase Manhattan Bank and the Export-Import Bank, a bank created in 1934 to support, through financing, exports of US goods and services, put numbers on an agenda that had initially been designed to learn about reactor technologies and their potential manufacturers, contact specialized consultants, and obtain political and financial support. The subject that focused the meetings with the State Department's nuclear energy advisers as well as with the banks was the high cost of nuclear-based electricity. Reports from the North Americans indicated the same thing as those made by the Spanish Ministry of Industry: the low economic profitability of nuclear-based energy. In this context, the Spaniards tried to convince the North Americans to act in two directions; on the one hand, facilitating the acquisition of foreign currency by Spanish companies and, on the other, encouraging a drop in prices of nuclear technology. The response from members of the US State Department was clear: as a trade-off, they asked the Spanish engineers to influence the Franco regime authorities to modify legislation and facilitate the arrival on Spanish soil of foreign companies interested in investing. As I have already mentioned, the Stabilization Plan of 1959 attempted to respond to this and other requests.

\section{III}

The visits to General Electric, Westinghouse, and Atomics International not only convinced the two Spanish engineers of the capabilities and guarantees offered by these manufacturers with their technologies; the narrative 
on these visits also later seduced the political and economic powers within the dictatorship as to the viability of the Spanish nuclear project.

Conversations, impressions, and secrets about nuclear technology were recorded in the travel log, as were public and private organizations, electricity companies, and construction and consulting companies responsible for regulating, financing, building, and managing these technologies. The names of the Spaniards' main interlocutors during their journey were also recorded. After analyzing this document from the perspective offered by the passage of time, I propose that this journey, along with the knowledge, practices, and experiences it put into circulation, explains many of the decisions - political, economic, and technological - that marked and conditioned the nuclear projects that came later.

The connection that the Spanish engineers established with Atomics International was later taken advantage of by the JEN. In 1961 this agency, which remember had been created to lead nuclear research and development in Spain, would choose this company to develop the prototype for a small reactor having 20 MWe of power, known as the DON project; a reactor that would use natural uranium as fuel, and be moderated by heavy water and cooled by an organic liquid. With its construction, the JEN wanted to study and plan the still incipient, at the time, Spanish nuclear program. The JEN physicists made many trips between 1961 and 1962 to the facilities at Atomics International to experiment and learn about the physics of the reactor core. Reactors of this type were then being developed in Ispra (Italy), Canada (WR-1, in Whiteshell, Manitoba) and the United States (HWOCR). But despite the political and institutional support the project received and the notable collaborative effort also made by the Spanish industry, the reactor was never built (Caro, 1995, pp. 99 and 121; Romero de Pablos and Sánchez Ron, 2001, pp. 171 et seq.; Cerrolaza, 2002, p.11; Romero de Pablos, 2019b, pp. 17 and 30).

Although there were technical reasons that justified interruption of the DON project, I would suggest this decision can also be interpreted politically: it was a project that had been promoted under autarkic policies of the early Franco regime; abandoning it not only distanced the technocrats from these policies, but also indicated a willingness to take research power away from the JEN in favor of the industry. This would be confirmed, as we will see, in the Law on Nuclear Energy of 1964.

The relationships established with Westinghouse and General Electric indeed lasted longer. Westinghouse was the manufacturer of the first power reactor to be put into operation in Spain at the Zorita nuclear power plant (Guadalajara) in 1969; and General Electric manufactured the second in Garoña (Burgos) in 1971. Both manufacturers would become the main suppliers of nuclear technology in Spain. (For a complete list of the nuclear projects that were planned in Spain from 1959 to the present see Rubio Varas and De la Torre, 2017, pp. 249-254).

General Nuclear Engineering, INTERNUCLEAR, EBASCO, Gibbs \& Hill and Bechtel, the consultants Cor- tines and Albisu contacted during their trip, would later, in the 1960s and 1970s, become the main advisers and interlocutors for the Spanish electricity companies. The practices they introduced, almost all of them unheard of in Spain at the time - one example, tenders to purchase technologies - legitimized and provided guarantees for organizational and management procedures without which it would have been difficult to build the Spanish nuclear facilities. The services offered by these consultants, based on knowledge and experience, influenced and reshaped Spanish companies mainly through the establishment of subsidiaries and alliances with local companies. One example of these alliances was the Empresarios Agrupados consortium that was created in 1971 following an agreement of Gibbs \& Hill with the subsidiaries of Banco Urquijo, Técnicas Reunidas and Estudios y Proyectos Técnicos Industriales S.A. (EPTISA). The economic historian Adoración Álvaro Moya considers that it was precisely the integration of this knowledge and its application to the organizational capabilities of Spanish engineering companies that allowed them to later compete successfully in international markets (Álvaro Moya, 2014, pp. 686-702).

Likewise, the request made by the representative of the US State Department to Gutiérrez-Cortines concerning introducing potential legislative changes that would favor the arrival of foreign companies on Spanish soil had its effect, giving nuclear technology an active role in the progressive process of economic liberalization that began in the 1960s in Spain. That is, international pressure, on the one hand, and pressure from the Spanish electrical industry, on the other, led to an opening in the markets that positively influenced the exploitation of nuclear electrical energy (Garrués-Irurzun and Rubio Mondéjar, 2017, pp. 67-96). This exploitation would not have been possible without clear reciprocal instrumentalization between political, economic, and industrial interests (Garrués-Irurzun and Rubio Mondéjar, 2018, pp. 12-15) nor without the financing the Franco government and Spanish electrical industry received from North American banks.

I already mentioned that the United States government had created the Eximbank in 1934 precisely to support exports of US products and services. This tool, which was used to protect and promote its nuclear technology through lending, was also useful for the North Americans to control and influence electricity sector policies and strategies in other countries. The Spanish case is very clear in this regard, but it was not the only one (on how the purchase of nuclear reactors for Zorita and Garoña was negotiated see Romero de Pablos, 2019b, pp. 42-51 and 77-87; on their financing see Rubio Varas and De la Torre, 2017, p. 127). A detailed study of Eximbank's movements shows that loans from the United States were behind the financing of more than half of the nuclear reactor sales that took place in the Western world between 1955 and 1985. This circumstance explains the predominance of North American nuclear technology facilities in the West (Rubio Varas and De la Torre, 2017, p. 124).

These strategies were also adopted by private Spanish banks, who knew how to take advantage of limitations 
in the Spanish financial system. If collaboration between the State and electricity companies was necessary, and its counterpart was that their interests would predominate in the design of the Spanish nuclear program (Garrués-Irurzun and Rubio Mondéjar, 2018, pp. 15-17), no less important was the influence on these electricity companies from the private Spanish banks, who also took care to establish a model for nuclear development that was favorable to their interests. For example, Nuclenor, in order to build the Garoña nuclear power plant, had to resort to a consortium made up of the five most important Spanish private banks (Bilbao, Vizcaya, Santander, Español de Crédito and Central), banks with which both Iberduero and Electra del Viesgo had historically been linked (Rubio Varas and De la Torre, 2017, p. 129). Nuclear investment, while strengthening relations between electricity companies and financial power, also strengthened banking corporations who had a bearing on decisions from the Spanish electricity sector (Garrués-Irurzun and $\mathrm{Ru}$ bio-Mondéjar, 2017, pp. 78-87).

Finally, the arrival of nuclear technology and, along with it, North American consultants and investments, also influenced the Spanish policies that regulated it. Many of the presumptions contained in the Law on Nuclear Energy of 1964, which established the legal system for the development and implementation of peaceful applications of nuclear energy, are difficult to understand without the new context that opened up in Spain after this trip in $1957 .{ }^{13}$ This law, which sought to impose order and control on this new form of energy, showcased a new scenario that was a reflection of the development and industrial momentum that stimulated construction of Spanish nuclear facilities.

The set of rules collected in the law reaffirmed, on the one hand, the JEN as a leading research center and as a regulatory body of the State; but it also gave Spanish electricity companies power over nuclear development that up to then they had not had. From then on, the JEN saw its realm of influence diminished and had to come to agreement with the electricity companies on many of the decisions that, until then, it had made alone. The weight of the international connection on nuclear development in Spain was also incorporated into the 1964 law. For the first time, it considered regulating and controlling international commitments the Spanish State had already acquired or had in mind to take on in nuclear matters. The close connection that had been established with the North American State and its industry, which would later also extend to France (Vandellòs) and Germany (Trillo), required regulation that until then had been absent, as it was considered unnecessary, from the Spanish legislative body.

IV

Recorded in this travel log, and in how it was narrated, were ways of experimenting, acquiring knowledge, designing and promoting research, regulating and financing it, and also ways of building power.
The artifacts, books, and materials that traveled from one side of the Atlantic to the other, along with nuclear technicians and experts, politicians and diplomats, technology manufacturers and expert consultants, while participating in the construction of North American scientific hegemony, also contributed to creating a new narrative of the Franco regime that showed Spain as a modern, internationally-connected State with technical capacity and political and business leadership capable of incorporating the latest atomic technologies.

Cortines and Albisu opened up a route that others would later travel once again. A route that allowed Spain to enter into international nuclear energy networks and internally present itself as a modern and capable country. On this first trip, both engineers confirmed that experimentation does not only take place in laboratories but also outside of them, and they established new ways of organizing, managing, and financing research spaces, whether public or private. And while always thinking of its application in a unique land like Spain in the second half of the 1950s, determined to assert its scientific and technical capabilities in a political context that was authoritarian and centralized.

This trip incorporated a series of state-of-the-art instruments into Spanish science and technology that, beyond being useful to start-up the Garoña nuclear power plant, contributed experiences and tools that reinforced the powers of the Franco dictatorship, the electricity companies and the engineers in an alliance that announced the technocratic Spain of the 1960s and early 1970s.

The consequences of this 1957 trip on the reconfiguration of how Spanish energy was mapped puts into question discourses, at least in the case of nuclear energy, that have argued that scientific and technological research played a secondary role in the political and economic changes that were initiated in Spain as of the Stabilization Plan of 1959. This trip showed and outlined itineraries that would be frequently repeated later, noted interlocutors with whom solid research links were established, introduced new experimental practices for organization and management within and outside laboratories and industrial facilities, and established guidelines and strategies that would design the agendas of the electricity companies and the scientific, economic, and industrial policies that made the Spanish nuclear facilities possible.

\section{ACKNOWLEDGMENTS}

I wish to thank Alfonso de la Torre, Juan Bros and Agustín Alonso of the Spanish Nuclear Society for facilitating my access to the Historical Archive of Garoña and especially Antonio Fernández de la Gala for making my work there possible. This research has been carried out within the framework of the FFI2016-76364-P and PID2019-106971GB-I00 projects funded by the Ministry of Science and Innovation. 


\section{NOTES}

1 Travel log by Mr. Cortines, who travelled to the US and Canada accompanied by Mr. Albisu. Bilbao, December 1957. Archivo Garoña.

2 A previous trip took Irish-born industrial engineer Jaime MacVeigh Alfós to the United States between 1948 and 1950. Although this originated in Banco Urquijo's interest in studying the start-up of the TALGO (Tren Articulado Ligero Goicoechea Oriol, an articulated light rail), the attention Mac-Veigh saw in the North American industry to apply the energy produced by the fission of uranium to obtain electrical energy gave him arguments that convinced the directors of the largest Spanish industrial bank of the possibilities that this new source of energy could have in Spain. This trip was the origin of the first study that was done on a possible Spanish nuclear program (Mac-Veigh, 1957) and of Tecnatom (Técnicas Atómicas, S.A.), a nuclear engineering firm that Banco Urquijo created in April 1957 to consider construction of Zorita, the first nuclear power plant that was connected to Red Eléctrica (the electrical network) in Spain (De la Torre, 2017, pp. 41-42; Rubio Varas and De la Torre, 2018).

3 Radioactive minerals. Law of 17 July 1958 amending section (b) of the second article of the Decree-Law of 22 October 1951 and laying down rules for their investigation and exploitation. Boletín Oficial del Estado (BOE, Official State Gazette) of 18 July 1958, 171, pp. 1274-1275.

4 The Nuclear Energy Board (JEN) was the public research body created in 1951 by the Franco regime to control, promote and direct the development of nuclear energy in Spain. Decree Law of 22 October 1951. BOE from 24 October 1951, pp. $4778-4779$.

5 In 1964, Francisco Albisu was the first Professor of Nuclear Technology in Spain and taught at the Faculty of Industrial Engineers in Bilbao.

6 This report was part of a library donated to Spain by the United States government in 1955 as a response, and in gratitude for, signing the Treaty on Nuclear Cooperation between the two countries. For this library's history and its role in the construction of North American scientific hegemony as of 1945 see Romero de Pablos (2018b)

7 Travel $\log$ by Mr. Cortines, who travelled to the US and Canada accompanied by Mr. Albisu. Bilbao, December 1957. Archivo Garoña, p. 5.

8 The Atomic Industrial Forum was the first industry association formed in 1953 for the purpose of promoting applications of nuclear technology. This association worked with the industry and the US government on policy development on nuclear issues and has played an important role in forming public opinion about nuclear energy. This association was the model for the Spanish Atomic Forum created in Spain in 1963. To learn about the role it played in legitimizing nuclear energy in Spain see Sánchez-Vázquez (2010) and Sánchez-Vázquez and Menéndez-Navarro (2015).

9 Travel log by Mr. Cortines, who travelled to the US and Canada accompanied by Mr. Albisu. Bilbao, December 1957. Archivo Garoña, p. 8.

10 The word pile was used to describe these early assemblies; the word reactor had not yet been applied.

11 Cooperation Agreement between the Spanish government and the government of the United States of America on civilian uses of atomic energy. Washington, July 19, 1955. Archivo Ministerio de Asuntos Exteriores.

12 This report-A Target for EURATOM - which was made by Louis Armand, Franz Etzel and Francesco Giordini, originated in the desire of the governments from Belgium, France, the Federal Republic of Germany, Italy, Luxembourg, and the Netherlands to know the amount of atomic energy that each of them could produce and to estimate the means they would have to use to do so. The full report is available at https://core.ac.uk/download/ pdf/7434607.pdf

13 Law 25/1964 on Nuclear Energy. BOE of 4 May 1964, 107, p. 7544.

\section{REFERENCES}

Albisu, F., and Echeverría, J. (1963) El cálculo numérico en el trabajo del reactor Arbi. Madrid: Forum Atómico Español.

Álvaro-Moya, A. (2014) "The Globalization of Knowledge-Based Services: Engineering Consulting in Spain, 1953-1975". Business History Review, 88 (4), pp. 681-707. doi: https://doi. org/10.1017/s0007680514000725

Barca Salom, F. X. (2000) "La cátedra Ferran Tallada (1955-1962). La Innovació tecnológica i la formació de l'enginyer". Scripta Nova. Revista Electrónica de Geografía y Ciencias Sociales, 69 (4). Available at: http://www.ub.edu/geocrit/sn-69-4.htm

Bleichmar, D. (2012) Visible Empire: botanical expeditions and visual culture in the Hispanic Enlightenment. Chicago: University of Chicago Press.

Bud, R. (2007) Penicillin: triumph and tragedy. Oxford University Press.

Camprubí, L. (2017). Los ingenieros de Franco: ciencia, catolicismo y Guerra Fría en el Estado franquista. Madrid: Crítica.

Caro, R., ed. (1995) Historia Nuclear de España. Madrid: Sociedad Nuclear Española.

Carreras, A., and Tafunell, X. (2007) Historia económica de la España contemporánea. Barcelona: Crítica.

Cerrolaza, J. Á. (2002) "Historia de la Energía Nuclear en España". IX Jornadas sobre la historia y Filosofía de la Ingeniería, la ciencia y la tecnología. Madrid: Instituto de la Ingeniería de España.

Daston, L., ed. (2000) Biographies of scientific objects. The University of Chicago Press.

De la Torre, J. (2017) "Who was Who in the Making of Spanish Nuclear Programme, c. 1950-1985". In M. Rubio-Varas and J. De la Torre, ed., The Economic History of Nuclear Energy in Spain Governance, Business and Finance. New York: Palgrave Macmillan, pp. 33-66.

Delgado Gómez-Escalonilla, L. (2015) "Modernizadores y tecnócratas. Estados Unidos ante la política educativa y científica de la España del desarrollo". En Historia y política: ideas, procesos y movimientos sociales, 34, pp. 113-146. doi: https://doi. org/10.18042/hp.34.05

Drogan, M. (2016) "The Nuclear imperative: Atoms for Peace and the development of U.S. policy on exporting nuclear power, 1953-1955". Diplomatic History, 40 (5), pp. 948-974. doi: https://doi.org/10.1093/dh/dhv049

Fernández Palomero, C., Álvarez del Buergo, L., and Sostoa Esquiroz, F. (1959) "Descripción y coste de construcción en España de un reactor tipo Argonaut". Energía Nuclear, 10, pp. 18-37.

Garrués, J. (2006). Las estrategias productivas, financieras e institucionales de Iberduero. Madrid: Iberdrola.

Garrués-Irurzun, J., and Rubio-Mondéjar, J. A. (2017) "The Nuclear Business and the Spanish Electric-Banking Oligopoly: The First Steps". In M. Rubio-Varas and J. De la Torre. ed., The Economic History of Nuclear Energy in Spain Governance, Business and Finance, New York: Palgrave Macmillan, pp. 67-98.

Garrués-Irurzun, J., and Rubio Mondéjar, J. A. (2018) "Entre el Estado empresario y el Estado regulador. El encaje de los intereses privados en el primer programa nuclear español (c.1951-1964)". FEG Working Papers Series. Documentos de trabajo de la Facultad de Ciencias Económicas y Empresariales de la Universidad de Granada, pp. 1-29.

Holl, J. M., Hewlett, R. G., and Harris R. R., (1997) Argonne National Laboratory, 1946-1996. Champaign-Urbana: University of Illinois Press.

Krige, J. (2006) "Atoms for Peace, scientific internationalism, and scientific intelligence". Osiris, 21 (1), pp. 161-181. doi: https:// doi.org/10.1086/507140

Krige, J. (2010) "Techno-utopian dreams, techno-political realities: The education of desire for the peaceful atom". In: M. D. Gordin, H. Tilley, and G. Prakash, eds., Utopia/dystopia: Conditions of historical possibility. Princeton: University Press, pp. 151-175. 
López-Ocón, L., Guijarro, V., and Pedrazuela, M. (2018) "Viajes con retorno en los institutos españoles”. En L. López-Ocón, V. Guijarro, and M. Pedrazuela, eds., Aulas abiertas. Profesores viajeros y renovación de la enseñanza secundaria en los países ibéricos (1900-1936), pp. 23-34.

Mac-Veigh Alfós, J. (1957). Ensayo sobre un programa de Energía Nuclear en España. Madrid: Servicio de Estudios, Banco Urquijo.

Marcus, G. H. (2010). Nuclear First: Milestones on the Road to Nuclear Power Development. American Nuclear Society, La Grange Park: Illinois.

Mateos, G., and Suárez-Díaz, E. (2015) “"We are not a rich country to waste our resources on expensive toys': Mexico's version of Atoms for Peace". History and Technology, 31 (3), pp. 243-258. doi: https://doi.org/10.1080/07341512.2015.11 28166

Medhurst, M. J. (1997) "Atoms for Peace and nuclear hegemony: The rhetorical structure of a Cold War campaign". Armed Forces \& Society, 23 (4), pp. 571-593. doi: https://doi. org/10.1177/0095327x9702300403

Osgood, K. (2006) Total Cold War: Eisenhower's secret propaganda battle at home and abroad. Lawrence: University Press of Kansas.

Pimentel, J. (2003) Testigos del mundo: ciencia, literatura y viajes en la Ilustración. Madrid: Marcial Pons Historia.

Reed, B. C. (2014). The history and science of the Manhattan project. Heidelberg: Springer.

Romero de Pablos, A. (2018a) "Prensa y tecnología en la España de Franco: del secreto a la política atómica pública". Dynamis, 38 (1), pp. 189-218.

Romero de Pablos, A. (2018b) "Historia de una biblioteca atómica". In L. Camprubí, X. Roqué, and F. Saez de Adana, eds., De la Guerra Fría al calentamiento global. Estados Unidos, España y el nuevo orden científico mundial. Madrid: Los libros de la Catarata, pp. 63-84.

Romero de Pablos, A. (2019a) "Knowledge that traveled between Italy and Spain during the Franco regime: the construction of radioactivity counters". História, Ciências, Saúde-Manguinhos, 26 (1), pp. 265-279. doi: https://doi.org/10.1590/s010459702019000100015
Romero de Pablos, A. (2019b) Las primeras centrales nucleares españolas. Actores, políticas y tecnologías. Madrid: Sociedad Nuclear Española.

Romero de Pablos, A., and Sánchez Ron, J. M. (2001) Energía nuclear en España. De la JEN al CIEMAT. Madrid: Doce Calles-CIEMAT.

Rubio-Varas, M., and De la Torre, J. ed. (2017), The Economic History of Nuclear Energy in Spain Governance, Business and Finance, New York: Palgrave Macmillan.

Rubio Varas, M., and De la Torre, J. (2018) "American Nuclear Training: científicos, ingenieros y empresarios españoles en los estados Unidos del desarrollo atómico". In L. Camprubí, X. Roqué, and F. Saez de Adana, eds., De la Guerra Fría al calentamiento global. Estados Unidos, España y el nuevo orden científico mundial. Madrid: Los libros de la Catarata, pp. 85-110.

Sánchez-Vázquez, L. (2010) La legitimación de la energía nuclear en España: el fórum atómico español (1962-1979), Tesis doctoral presentada en el Programa de Doctorado Paz, conflictos y democracia. Editorial de la Universidad de Granada.

Sánchez-Vázquez, L., and Menéndez-Navarro, A. (2015) "Nuclear Energy in the Public Sphere: Anti-Nuclear Movements vs. Industrial Lobbies in Spain (1962-1979)". Minerva, 53, pp. 69-88. doi: https://doi.org/10.1007/s11024-014-9263-0

Santesmases, María J. (2007) "Viajes y memoria: las ciencias en España antes y después de la guerra civil". Asclepio, 59 (2), pp. 213-230. doi: https://doi.org/10.3989/asclepio.2007.v59.i2.238

Secord, J. A. (2004) "Knowledge in transit". Isis, 95(4), pp. 654672. https://doi.org/10.1086/430657

Urdangarin Altuna, C. (2018). Fundación LABEIN. Auñamendi Encyclopedia. Available at: http://aunamendi.eusko-ikaskuntza. eus/en/fundacion-labein/ar-83914/

Velasco Morgado, R. (2019). "Pediatría y cultura de viaje: los pensionados españoles y la apropiación del laboratorio en la periferia, 1907-1939". História, Ciências, Saúde-Manguinhos, 26 (3), pp. 841-862. doi: https://doi.org/10.1590/s010459702019000300007

Zachmann, K. (2011) "Atoms for peace and radiation for safety. How to build trust in irradiated foods in Cold War Europe and beyond". History and Technology, 27, pp. 65-90. doi: https:// doi.org/10.1080/07341512.2011.548973 